Abstracta Iranica Abstracta Iranica

Revue bibliographique pour le domaine irano-aryen

Volume 24 | 2003

Comptes rendus des publications de 2001

\title{
" On the Date of the Oxus Gold Scabbard and Other Achaemenid Matters ». BAI 12, 1998 (2001), pp. 231-248.
}

Rémy Boucharlat

\section{(2) OpenEdition}

Journals

Édition électronique

URL : http://journals.openedition.org/abstractairanica/34340

DOI : 10.4000/abstractairanica.34340

ISSN : 1961-960X

Éditeur :

CNRS (UMR 7528 Mondes iraniens et indiens), Éditions de l'IFRI

Édition imprimée

Date de publication : 15 mai 2003

ISSN : 0240-8910

Référence électronique

Rémy Boucharlat, « "On the Date of the Oxus Gold Scabbard and Other Achaemenid Matters ». BA/ 12, 1998 (2001), pp. 231-248. », Abstracta Iranica [En ligne], Volume 24 | 2003, document 80, mis en ligne le 05 janvier 2010, consulté le 25 septembre 2020. URL : http://journals.openedition.org/ abstractairanica/34340 ; DOI : https://doi.org/10.4000/abstractairanica.34340

Ce document a été généré automatiquement le 25 septembre 2020.

Tous droits réservés 


\section{«On the Date of the Oxus Gold} Scabbard and Other Achaemenid Matters ». BAI 12, 1998 (2001), pp. 231-248.

\section{Rémy Boucharlat}

Nouvelle étude du fourreau d'épée en or du trésor de l'Oxus. Avec de solides arguments, l'A. rejette l'hypothèse d'une création de l'époque mède, même si certains détails paraissent archaïsants. En cela, l'A. y reconnaît une illustration de la volonté d'un roi perse (entre Darius et Artaxerxès) d'affirmer sa légitimité en diffusant des images qui mettaient en valeur ses ancêtres aussi lointains que possible. Pour sa démonstration, il compare cet objet à la production de «faux anciens" comme par exemple probablement les tablettes d'Ariaramnès et Arsamès. Il n'est pas sûr que l'on puisse mettre sur le même plan des objets aussi différents.

INDEX

Thèmes : 3.2.2. Pré-Achéménides et Achéménides

\section{AUTEURS}

RÉMY BOUCHARLAT

CNRS - Lyon 